\title{
Sociobiology
}

RESEARCH ARTICLE - ANTS

\section{Population Dynamics of Acromyrmex crassispinus (Forel) (Hymenoptera: Formicidae) and Attacks on Pinus taeda Linnaeus (Pinaceae) plantations}

\author{
MA NICKELE ${ }^{1}$, W REIS FILHO ${ }^{2}$ \\ 1 - Universidade Federal do Paraná, Curitiba, PR, Brazil \\ 2 - Epagri/Embrapa Florestas, Colombo, PR, Brazil
}

\section{Article History}

Edited by

Kleber Del-Claro, UFU, Brazil

Received 21 May 2014

Initial acceptance 21 September 2014

Final acceptance 25 September 2014

\section{Keywords}

Control, leaf-cutting ants, nest density, nuptial flight, spatial distribution.

\section{Corresponding author}

Mariane Aparecida Nickele

Universidade Federal do Paraná

Departamento de Zoologia, Caixa Postal 19020, CEP 81531-980 Curitiba, PR, Brazil

E-Mail: manickele@ufpr.br

\begin{abstract}
This work aimed to study the population dynamics of Acromyrmex crassispinus (Forel) in Pinus taeda L. plantations, evaluating the density and spatial distribution of nests over time, inferring about the period of the first nuptial flight of $A$. crassispinus colonies, and evaluating the levels of attack of this leaf-cutting ant on P. taeda plants. Assessments were performed monthly in the first year after planting, every three months until the third year and every six months until the plantation was six years old. The presence of nests was observed only after 15 months after planting. The nest density gradually increased until the planting completed 30 months, and decreased when the forest canopy began to close (after 54 months). Spatial distribution of $A$. crassispinus nests was random. Probably, the first nuptial flight of an A. crassispinus colony occurred after the third year of the colony foundation. Pinus taeda plants were not attacked by $A$. crassispinus throughout the evaluation period. Then, when dealing with a replanting area of Pinus plantation, where the previous forest has not been subject to pruning nor thinning, the problem with $A$. crassispinus is almost null if the clearcutting and the new planting occur during the winter. In this case, leaf-cutting ants control can be alleviated and it is not necessary to carry out systematic control of ants where $A$. crassispinus is the predominant leaf cutting ant species. Acromyrmex crassispinus control should be done only if nests are located or if attacked plants by ants are detected.
\end{abstract}

\section{Introduction}

Ants belonging to Attini tribe cultivate a symbiotic fungus inside their nests. Foragers of Atta and Acromyrmex genera cut fresh fragments of leaves and other plant parts and carry them to their nests to be used as substrate for the fungus cultivation (De Fine Licht \& Boomsma, 2010).

Leaf-cutting ants (Atta and Acromyrmex) are among the most polymorphic of all social insects and show an extensive division of labor among size castes. The division of labor among different ant worker castes improves efficiency and benefits the colony as a whole (Hölldobler \& Wilson, 1990). Leaf-cutting ants have a particularly complex foraging process involving individual scouts and mass recruitment (Jaffe \& Howse, 1979), mass traffic flows involving tens of thousands of outbound and returning workers (Fowler et al., 1986), and processing of leaf fragments by workers in the nest before they take them to the fungal gardens. Foraging is conducted by medium to large size workers that cut and collect small vegetation fragments, which they transport along trails to the nest. In the nest, this material is further processed by smaller workers and incorporated into the fungus garden (Weber, 1972, Hölldobler \& Wilson, 1990).

Leaf-cutting ants are possibly the most important herbivores of terrestrial environments throughout the Neotropics, leading to considerable economic losses to a variety of crops. These ants are considered the most important pest of forest plantations in Brazil due to their intense and constant attacks on plants at all stages of development. However, the age of plants can influence the vulnerability of the forest plantation to the damage caused by these ants. Seedlings planted in infested areas by leaf-cutting ants have no chance of survival, as they can be easily destroyed by the ants (Cherrett, 1986; Vasconcelos \& Cherrett, 1997).

Leaf-cutting ants are usually controlled by applying insecticides from different chemical groups and different formulations (granulated baits, fogging, and dust) (Boareto \& Forti, 1997). However, these products cause serious environmental 
problems because they are toxic to non-target animals and persist in the environment (Ying \& Kookana, 2006).

The information about insect densities in cultivated areas is essential, because it allows inferences about the potential damage of the species (Pereira et al., 1999). The knowledge of the density and spatial distribution of pests is also essential to perform control strategies, to improve sample technics, or to estimate economic losses of those insects (Croft \& Hoyt, 1983, Pereira et al., 1999).

This study aimed to study the population dynamics of Acromyrmex crassispinus (Forel), the most common leaf-cutting ant species in southern Brazil, in Pinus taeda L. plantations. Evaluating the density and spatial distribution of nests over time, inferring about the period of the first nuptial flight of A. crassispinus colonies, as well as, evaluating the levels of attack of this leaf-cutting ant on P. taeda plants.

\section{Material and methods}

Experiments were carried out in São Mateus do Sul city (255' $56,33^{\prime \prime} \mathrm{S}, 50^{\circ} 23^{\prime} 49,26^{\prime \prime} \mathrm{W}$, alt. $\left.766 \mathrm{~m}\right)$ state of Parana, Brazil. Recently-planted P. taeda plantations were selected (replanted areas, in other words, Pinus was previously planted in the area). In the previous planting there were approximately 1.300 plants per hectare, and it has not been subject to pruning nor thinning. The clear cutting was done in June-July, 2007 and the new planting was done in August, 2007 (1.600 plants ha ${ }^{-1}$ ).

Three plots of one hectare without control against ants were demarcated (100x100 m). The number (density) and the size of Acromyrmex nests in the total area of each plot were recorded. All nests were measured and the major axis length was taken as the approximated diameter of the nest. Nests were categorized into three size classes: Class I, up to $30 \mathrm{~cm}$ in diameter; Class II, between 31 and $60 \mathrm{~cm}$, and Class III, more than $61 \mathrm{~cm}$ (Nickele et al., 2009). The evaluations of density and size of nests were performed monthly in the first year after planting, every three months until the third year and every six months until the plantation was six years old (from September 2007 until August 2013).

The location of Acromyrmex nests in the total area of each plot was recorded. Maps with the location of Acromyrmex nests in each plot were made to study the spatial distributions. The evaluations of spatial distributions of nests were performed in the same period than the evaluations of density and size of nests (from September 2007 until August 2013).

The total sampling area $\left(30,000 \mathrm{~m}^{2}\right)$ was subdivided into 192 sampling units of $156.25 \mathrm{~m}^{2}$, based in Nickele et al., 2010. The data of the location of $A$. crassispinus nests in each evaluation were tested to see if they fitted Poisson's distribution (that represents the random spatial distribution), positive binomial distribution (that represents the regular spatial distribution) or negative binomial distribution (that represents the aggregated spatial distribution), following the expressions, as Bliss and Fisher (1953), Davis (1993) and Krebs (1989).
The model fits the original data adequately when the observed and expected frequencies are in close proximity. Such proximity was tested by the chi-square test $\left(\chi^{2}\right)$, given by:

$\chi^{2}=\sum_{i=1}^{N_{c}} \frac{\left(F O_{i}-F E_{i}\right)^{2}}{F E_{i}} \quad$, where: $F O_{i}=$ observed frequency in class $i$; number of classes in the frequency distribution. The number of degrees of freedom in the $\chi^{2}$ test is given by: $d . f .=n c$ - $n p-1$, where: $n p=$ number of parameters estimated in the sample. The test criterion adopted was that the fitting of the distribution under study should be rejected at the $5 \%$ probability level if: $\chi^{2} \geq \chi_{(n c-n p-1 ; \alpha) \text {. }}^{2}$

To study the period of occurrence of the first nuptial flight of $A$. crassispinus, 10 nests were evaluated monthly during Spring of 2009 and 10 nests were evaluated monthly during Spring of 2010. We selected the largest nests present in the area. During the Spring of 2009, sticky traps were installed around 10 nests to collect winged male or female ants. In the Spring of 2010, we decided to open 10 nests looking for reproductive ants.

All P. taeda plants in each plot (census) were evaluated, recording the number of plants that were attacked by leafcutting ants. The evaluations were performed monthly in the first year after planting, every three months until the third year and every six months until the plantation was six years old (from September 2007 until August 2013).

\section{Results}

\section{Density and size of the A. crassispinus nests}

The presence of $A$. crassispinus nests was observed only from 15 months after planting (Spring/2008), where there was one nest per hectare, in average (Figure 1). Nest density gradually increased in subsequent months, and 30 months after planting (Summer/2010) there was, in average, 26 nests per hectare. However, a substantial decrease in nest density happened over time. At 54 months after planting, the forest canopy closed and at 72 months after planting, there was only 0.33 nests per hectare, in average. The few nests observed after 54 months after planting were located near tree gaps in the middle of planting.

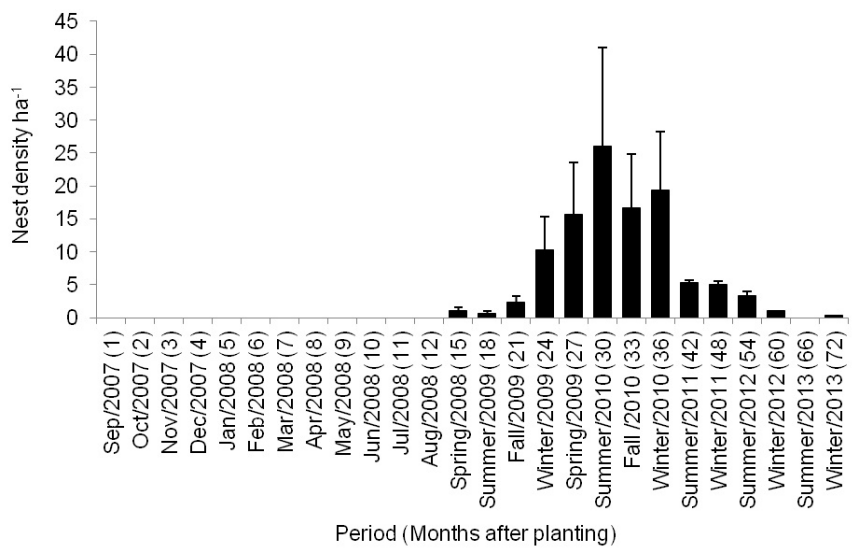

Fig 1. Density (mean \pm standard deviation) of Acromyrmex crassispinus nests in a Pinus taeda plantation. São Mateus do Sul, PR, Brazil, 2007-2013. 


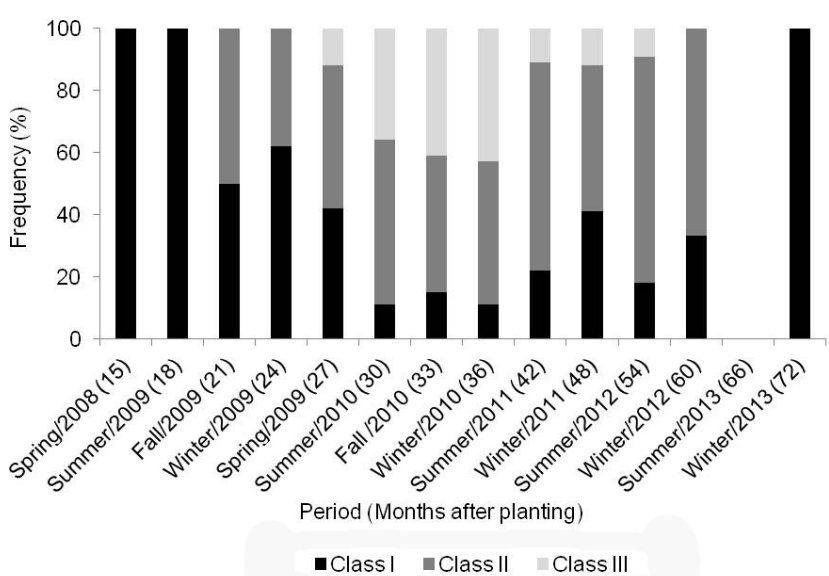

Fig 2. Frequency of Acromyrmex crassispinus nests in a Pinus taeda planting, by size class: Class I, up to $30 \mathrm{~cm}$ in diameter, Class II, between 31 and $60 \mathrm{~cm}$; and Class III, greater than $61 \mathrm{~cm}$. São Mateus do Sul, PR, Brazil, 2008-2013.
Until 18 months after planting, all nests were class I size (smaller than $30 \mathrm{~cm}$ in diameter) (Figure 2). Nests with class III size (over $61 \mathrm{~cm}$ ) were observed 27 months after planting. When nest density reached a peak (30 months after planting), 11, 53 and $36 \%$ of nests were classes I, II and III, respectively. At 72 months after planting, the only one nest found was class I size.

\section{Spatial distribution of A. crassispinus nests}

Until 24 months after planting, the spatial distribution of A. crassispinus nests fitted with the Poisson distribution model, because the chi-square values were not significant. It represents random spatial distribution. The other models could not be tested due to insufficient frequency classes for the chi-square test, which was attributed to the low occurrence of nests in the sampled areas (Table 1).

Table 1. Chi-square test of adherence of observed frequencies to the expected Poisson distributions, positive and negative binomial distributions for Acromyrmex crassispinus nests in a Pinus taeda plantation.

\begin{tabular}{|c|c|c|c|c|c|c|c|c|}
\hline \multirow[t]{2}{*}{$\begin{array}{l}\text { Months after } \\
\text { planting }\end{array}$} & \multirow[t]{2}{*}{ Period } & \multirow[t]{2}{*}{$\begin{array}{l}\text { Number of } \\
\text { nests }\end{array}$} & \multicolumn{2}{|c|}{ Poisson } & \multicolumn{2}{|c|}{$\begin{array}{c}\text { Positive } \\
\text { binomial }\end{array}$} & \multicolumn{2}{|c|}{$\begin{array}{l}\text { Negativa } \\
\text { binomial }\end{array}$} \\
\hline & & & $\chi^{2}$ & D.F. ${ }^{1}$ & $\chi^{2}$ & D.F. ${ }^{1}$ & $\chi^{2}$ & D.F. ${ }^{1}$ \\
\hline 1 & Sep/07 & 0 & - & - & - & - & - & - \\
\hline 2 & Oct $/ 07$ & 0 & - & - & - & - & - & - \\
\hline 3 & Nov/07 & 0 & - & - & - & - & - & - \\
\hline 4 & Dec/07 & 0 & - & - & - & - & - & - \\
\hline 5 & $\mathrm{Jan} / 08$ & 0 & - & - & - & - & - & - \\
\hline 6 & $\mathrm{Feb} / 08$ & 0 & - & - & - & - & - & - \\
\hline 7 & Mar/08 & 0 & - & - & - & - & - & - \\
\hline 8 & Apr/08 & 0 & - & - & - & - & - & - \\
\hline 9 & May/08 & 0 & - & - & - & - & - & - \\
\hline 10 & Jun/08 & 0 & - & - & - & - & - & - \\
\hline 11 & $\mathrm{Jul} / 08$ & 0 & - & - & - & - & - & - \\
\hline 12 & Aug/08 & 0 & - & - & - & - & - & - \\
\hline 15 & Spring/2008 & 3 & $0,00006^{\mathrm{NS}}$ & 1 & $\mathrm{i}$ & $\mathrm{i}$ & $\mathrm{i}$ & $\mathrm{i}$ \\
\hline 18 & Summer/2009 & 2 & $0,00006^{\mathrm{NS}}$ & 1 & i & $\mathrm{i}$ & $\mathrm{i}$ & $\mathrm{i}$ \\
\hline 21 & Fall/2009 & 7 & $0,009^{\mathrm{NS}}$ & 2 & $\mathrm{i}$ & $\mathrm{i}$ & $\mathrm{i}$ & $\mathrm{i}$ \\
\hline 24 & Winter/2009 & 31 & $1,18^{\mathrm{NS}}$ & 2 & $\mathrm{i}$ & $\mathrm{i}$ & $1,81^{\mathrm{NS}}$ & 1 \\
\hline 27 & Spring/2009 & 47 & $0,41^{\mathrm{NS}}$ & 2 & $1,33^{\mathrm{NS}}$ & 1 & $1,49^{\mathrm{NS}}$ & 1 \\
\hline 30 & Summer/2010 & 78 & $6,51^{\mathrm{NS}}$ & 3 & $8,39 *$ & 1 & $44,21 *$ & 2 \\
\hline 33 & Fall $/ 2010$ & 50 & $3,83^{\mathrm{NS}}$ & 3 & $4,16^{*}$ & 1 & $0,72^{\mathrm{NS}}$ & 1 \\
\hline 36 & Winter/2010 & 58 & $5,61^{\mathrm{NS}}$ & 3 & $6,05^{*}$ & 1 & $2,09^{\mathrm{NS}}$ & 1 \\
\hline 42 & Summer/2011 & 15 & $1,74^{\mathrm{NS}}$ & 2 & $\mathrm{i}$ & $\mathrm{i}$ & $\mathrm{i}$ & $\mathrm{i}$ \\
\hline 48 & Winter/2011 & 14 & 0,07 NS & 2 & $\mathrm{i}$ & $\mathrm{i}$ & $\mathrm{i}$ & $\mathrm{i}$ \\
\hline 54 & Summer/2012 & 11 & $0,04^{\mathrm{NS}}$ & 2 & $\mathrm{i}$ & $\mathrm{i}$ & $\mathrm{i}$ & $\mathrm{i}$ \\
\hline 60 & Winter/2012 & 3 & $0,00006^{\mathrm{NS}}$ & 1 & $\mathrm{i}$ & $\mathrm{i}$ & $\mathrm{i}$ & $\mathrm{i}$ \\
\hline 66 & Summer/2013 & 0 & - & - & - & - & - & - \\
\hline 72 & Winter/2013 & 1 & $0,00005^{\mathrm{NS}}$ & 1 & $\mathrm{i}$ & $\mathrm{i}$ & $\mathrm{i}$ & $\mathrm{i}$ \\
\hline
\end{tabular}


From 27 to 30 months after planting, there was adjustment with the Poisson model. However, at 27 months there were also adjustments with the positive and negative binomial distribution. The best adjustment is represented by the frequency distribution with the lower value of the chi-square calculated. In this case, the best fit was with the Poisson distribution, indicating random spatial distribution. (Table 1).

From 33 to 36 months after planting, there was adjustment to both, Poisson distribution and negative binomial distribution. In this case, the best adjustment was to the negative binomial distribution, because it showed the lowest value of the chisquare calculated (Table 1). It represents aggregated spatial distribution in this period. In these evaluations, there was a higher concentration of nests in an edge of the area.

From 42 to 72 months after planting, there was adjustment with the Poisson model again, indicating that the spatial distribution of $A$. crassispinus nests is random in most samplings.

\section{Nuptial flights of A. crassispinus}

In the spring of 2009 , winged male or female ants were not observed in the nests sampled. In the spring of 2010 , winged ants were observed in 50,20, 20 and $10 \%$ of the nests sampled in September, October, November and December, respectively (Table 2). Males emerge earlier than females. In several nests, while males were already adult, females were still in the pupal stage.

The average diameter of nests monitored during the spring of 2010 was of $92.1 \pm 18.51 \mathrm{~cm}$ (mean \pm SD). The colonies with nest diameter below the average size contained no winged

Table 2: Occurrence of reproductive ants (winged male or female ants) in Acromyrmex crassispinus nests.

\begin{tabular}{|c|c|c|c|c|c|c|}
\hline Colony & $\begin{array}{c}\text { Diameter } \\
\text { of the } \\
\text { nest }(\mathbf{c m})\end{array}$ & Sep/10 & Oct $/ 10$ & Nov/10 & Dec/10 & Summer/11 \\
\hline 1 & 75 & 0 & 0 & 0 & 0 & Alive \\
\hline 2 & 80 & 0 & 0 & 0 & 0 & $\begin{array}{c}\text { Dead/ } \\
\text { Emigrated }\end{array}$ \\
\hline 3 & 98 & 1 & 0 & 0 & 0 & $\begin{array}{c}\text { Dead/ } \\
\text { Emigrated }\end{array}$ \\
\hline 4 & 82 & 0 & 0 & 0 & 0 & Alive \\
\hline 5 & 98 & 1 & 1 & 1 & 0 & $\begin{array}{c}\text { Dead/ } \\
\text { Emigrated }\end{array}$ \\
\hline 6 & 62 & 0 & 0 & 0 & 0 & Alive \\
\hline 7 & 98 & 0 & 0 & 1 & 1 & $\begin{array}{c}\text { Dead/ } \\
\text { Emigrated }\end{array}$ \\
\hline 8 & 98 & 1 & 1 & 0 & 0 & $\begin{array}{c}\text { Dead/ } \\
\text { Emigrated }\end{array}$ \\
\hline 9 & 100 & 1 & 0 & 0 & 0 & $\begin{array}{c}\text { Dead/ } \\
\text { Emigrated }\end{array}$ \\
\hline 10 & 130 & 1 & 0 & 0 & 0 & $\begin{array}{c}\text { Dead/ } \\
\text { Emigrated }\end{array}$ \\
\hline
\end{tabular}

(0) Absent; (1) Present. ants. In contrast, colonies with nest diameter greater than average size contained winged ants (Table 2).

After the nuptial flight, nests were with one aspect that they were languishing or dying. In the evaluation during the next station (Summer/2011), all of these nests were empty, in other words, the colony probably emigrated or died (Table 2).

\section{Attacks of A. crassispinus on P. taeda plants}

During the first 15 months after planting there were no P. taeda plants attacked by ants in the plots evaluated. After this period, wherein $A$. crassispinus nests started to be located in the area, ants attacked some native plants or $P$. taeda plants that were growing between the planting lines. However, plants with commercial interest suffered no attacks of leaf-cutting ants throughout the observation period.

\section{Discussion}

Acromyrmex crassispinus is the most common leafcutting ant species in southern Brazil (Rando \& Forti, 2005). However, nest density and spatial distribution of this ant species have never been studied in the same area for a period longer than one year. In this study, A. crassispinus nests were located only when planting reached 15 months of age. In the previous rotation of the planting had not been performed any activity of pruning or thinning plants, which contributed to the lack of $A$. crassispinus nests, since the canopy was completely closed and without the direct sunlight within the planting, and absence of undergrowth, with a layer of dried needles covering the soil. These ants have preference for nesting in open areas (Nickele et al., 2009). The clearcutting of the previous planting occurred during the winter of 2007, that is, before the period of nuptial flight of the ants, which occurs during the spring, to found new colonies (DiehlFleig, 1993; Reis Filho \& Oliveira, 2002). When the area was replanted there were no ant nests and it is suspected that the $A$. crassispinus nests settled in the area from the spring of 2007, but as young colonies of Acromyrmex are not easily located, they were observed only at 15 months after planting (spring 2008). This fact leads us to infer that when $A$. crassispinus nests started to be located, the colonies were more than one year old.

Young colonies of Acromyrmex are not easily located, due to the size of its population. Incipient nests of Acromyrmex octospinosus (Reich) have only 3-7 workers (FernandezMarin et al., 2003). In contrast, initial nests of Atta spp. may contain approximately 100 workers when they were 3 months old and they can be easily located (Autuori, 1942).

The density of nests belonging to class I size (smaller than $30 \mathrm{~cm}$ ) remained constant throughout the evaluation period, because of the nuptial flights that occurred in subsequent years. The establishment of a new nest starts with the nuptial flights, wherein the winged virgin females run away of their original nest and they are inseminated by one or more males. After mating, queens seek the most appropriate place to start building 
their nest (Hölldobler \& Wilson, 1990). Initial plantations are suitable areas for installation and establishment of queens shortly after the nuptial flight. Queens seek sites destituted of vegetation to start building their nest (Vasconcelos, 1990), because incipient colonies require some degree of insolation (Jaffe \& Vilela, 1989) and because the first workers are smaller than the smallest workers produced by a mature colony and those workers forage efficiently in herbaceous plants (Wetterer, 1994).

The density of $A$. crassispinus nests gradually increased when planting completed 30-36 months of age, and decreased when the forest canopy began to close (after 54 months). These data are similar to results found by Nickele et al. (2009) in Rio Negrinho and Três Barras, SC, Brazil, where the density of A. crassispinus nests was lower in early development of $P$. taeda planting, almost doubling in three years old plantations and suffering a reduction when the forest was six years old. Zanetti et al. (2000) found a similar situation in the nest density of Atta spp. in Eucalyptus plantations in João Pinheiro, MG, Brazil.

The reason for the occurrence of this situation is that in newly planted areas, new nests settle from the time at which the nuptial fligth occur. In the course of time, there is an increase in nest density in all size classes, because colonies grown and nuptial fligth occur every year. The fact that the nest density decrease when plants grown may be related to the closure of the forest canopy, which may hinder the installation of new colonies, or could be related to the low diversity of understory, in other words, the lack of plant resources for ant foraging (Zanetti et al., 2000; Nickele et al., 2009).

At 60 months after planting, the nests were found near clearings and were class I and II size. Acromyrmex crassispinus showed the same behavior in a 6 years old plantation of $P$. taeda in Três Barras, SC city (Nickele et al., 2009). The leaf cutting ants found in primary native forests also are concentrated in areas near clearings, where the sun and pioneer plant species are more available to the colonies (Wetterer, 1994, FarjiBrener, 2001, Peñaloza \& Farji-Brener, 2003).

The spatial distribution of $A$. crassispinus nests was random in most samples, similar to that described in Nickele et al. (2010). The random distribution of leaf cutting ants also had been documented by Zanuncio et al. (2002), Caldeira et al. (2005) and Cantarelli et al. (2006). The random distribution occurs when site conditions are similar, that is, in areas where there is homogeneity in temperature, soil type, cultural practices, and so forth. Queens fall randomly in the areas and establish their nests anywhere in the forest (Caldeira et al., 2005). In contrast, Acromyrmex balzani (Emery) and Acromyrmex landolti Forel have aggregated spatial distribution, in fragments of grassland. This type of distributions may reflect the habitat heterogeneity or can be relate to the strategy of colony foundation (SousaSouto et al., 2013; Silva Junior et al., 2013).

Reproductive ants (winged males and females ants) only appear in the colonies at certain periods of the year to conduct the nuptial flight and founding new colonies (Hölldobler \& Wilson, 1990). The first nuptial flight of Atta occurs only after the colonies are 3 years old (Autuori, 1941), being repeated every year after this period during the spring. The nuptial flight of Acromyrmex species also occurs during the spring, however, it is not known how old the colony is when first nuptial flight occur. Probably, the A. crassispinus colonies found in the experimental area had similar age to the age of the plantation. The clearcutting of the earlier planting occurred before the nuptial flight of the ants, suggesting that nests only settled in the area from the spring of 2007 (along with the new planting), since this leaf cutting ant species prefers nidificate in areas opened. The presence of reproductive ants in sampled colonies was observed only from the spring of 2010, that is, three years after planting. This suggests that the first nuptial flight of an A. crassispinus colony also occurs after the third year of the colony foundation, as occurs in Atta species.

Colonies that performed the nuptial flight had nests size greater than $92 \mathrm{~cm}$ in diameter, showing that nest size is related to the age of the colony. In the first evaluations, all nests were less than $30 \mathrm{~cm}$ in diameter. However, over time nests were recorded with different size classes.

All nests emigrated or died after the occurrence of the nuptial flight. The emigration of $A$. crassispinus colonies is very common, regardless of the colony size (Nickele et al., 2009). A leaf cutting ant colony can emigrate after suffering some sort of disturbance, such as intoxication with formicide baits, floods, lack of resources for foraging or intra and interspecific competitive interactions (Nickele et al., 2012a). Probably, in this study there was the emigration of the $A$. crassispinus colonies after the nuptial flight, because it is assumed that it is more advantageous to this ant species build a new nest than to reform the old one, since $A$. crassispinus builds superficial nests with a single camera located in a shallow excavation. Colony death is unlikely, since Acromyrmex queens can live for up to 10 years, at least under laboratory conditions (Weber, 1972). The fact is that the colonies disappeared after the nuptial flight, but it is unclear what happened to the colony. This subject deserves further investigation to clarify aspects that are still unclear.

There were no $P$. taeda plants attacked by ants in the plots evaluated. When the A. crassispinus nests began to be observed in the area and began foraging with greater intensity, $P$. taeda plants were already more than one year old, that is, they were no more so vulnerable to Acromyrmex attacks. In addition, there were several options of native plants between the pine rows after one year of planting. So, ants preferred foraging in plants derived from natural regeneration and they did not attack the plants of commercial interest, which is exotic. Nickele et al. (2012b) found that higher percentages of Acromyrmex attack in P. taeda plants occurs in the first months after planting, with larger impact in the first 30 days, in reform areas where earlier planting suffered pruning and thinning. In this case, $A$. crassispinus nests have been observed since the beginning of planting and the first months after planting, ants had no options of native plant resources for foraging due to soil preparation for planting (Nickele et al., 2009). 
Another factor that contributed to ants do not attack plants after 15 months, is that older plants have a higher amount of chemical defenses against herbivores, being less susceptible to ant attacks than younger plants (Farji -Brener, 2001; Mundim et al., 2009).

When dealing with a replanting area of Pinus plantation, where the previous forest has not been subject to pruning nor thinning, the problem with A. crassispinus is almost null if the clear cutting and the new planting occur during the winter. This occurs because the number of nests in the previous planting is very low or nonexistent, because this ant species prefers nidificate in open areas. If the new planting is done before the nuptial flight period, plants will not be as vulnerable to A. crassispinus attack when new nests settle and begin to forage with greater intensity. In this case, leaf-cutting ants control can be alleviated and it is not necessary to carry out systematic control of ants when $A$. crassispinus is the predominant species. Acromyrmex crassispinus control should be done only if nests are located or if attacked plants by ants are detected.

\section{Acknowledgements}

We thank Nádia Caldato, Priscila Strapasson and Mila Ferraz de Oliveira Martins for their assistance during field work. We also thank the Coordenação de Aperfeiçoamento de Pessoal de Nível Superior (CAPES) for granting fellowship to M.A.N, and MWV Rigesa for granting the study area.

\section{References}

Autuori, M. (1941). Contribuição para o conhecimento da saúva (Atta spp. - Hymenoptera - Formicidae). I - Evolução do sauveiro (Atta sexdens rubropilosa, Forel, 1908). Arquivos do Instituto Biológico, 12: 197-228.

Autuori, M. (1942). Contribuição para o conhecimento da saúva (Atta spp. - Hymenoptera - Formicidae). II. O sauveiro inicial (Atta sexdens rubropilosa, Forel, 1908). Arquivos do Instituto Biológico, 13: 67-86.

Abraf. (2011). Anuário estatístico da ABRAF 2012: ano base 2010. Brasília: ABRAF, 150p.

Boaretto, M. A. C. \&Forti, L. C. (1997). Perspectivas no controle de formigas cortadeiras. Série técnica IPEF, 11:31-46.

Caldeira, M. C., Zanetti, R., Morais, J. C. \& Zanúncio, J. C. (2005). Distribuição espacial de sauveiros (Hymenoptera: Formicidae) em eucaliptais. Cerne, 11: 34-39.

Cantarelli,E.B.,Costa,E.C.,Zanetti,R.\& Pezzutti,R. V.(2006).Plano de amostragem de Acromyrmex spp. (Hymenoptera: Formicidae) em áreas de pré-plantio de Pinus spp. Ciência Rural, 36: 385-390.

Cherrett, J.M. (1983). The economic importance and control of leafcutting ants. In: VINSON, S.B. (Ed.). Economic impact and control of social insects. New York: Praeger, 1986. p.165-192.
Croft, B. A. \&Hoyt, S. C. (1983). Integrated management of insects pests of pome and stone fruits. New York, Wiley Interscience, $454 \mathrm{p}$.

Davis, P. M. (1993). Statistics for describing populations. p. 33-54. In: Pedigo, L.; Buntin, G. D. (Eds.). Handbook of sampling methods for arthropods in agriculture. Boca Raton, CRC Press, $714 \mathrm{p}$.

De Fine Licht, H.H. \& Boomsma, J.J. (2010). Forage collection, substrate preparation, and diet composition in fungus-growing ants. Ecological Entomology, 35: 259-269. doi: 10.1111/j.13652311.2010.01193.x

Diehl-Fleig, E. (1993). Sex ratio and nuptial flight pattern of the leaf-cutting ants Acromyrmex heyeri and A. striatus (Hymenoptera, Formicidae). Insectes Sociaux, 40: 111-113.

Fernández-Marín, H., Zimmerman, J.K. \& Wcislo, W.T. (2003). Nest-founding in Acromyrmex octospinosus (Hymenoptera, Formicidae, Attini): demography and putative prophylactic behaviours. Insectes Sociaux, 50: 304-308. doi:10.1007/s00040-003-0687-z

Farji-Brener, A.G. (2001). Why are leaf-cutting ants more common in early secondary forests than in old-growth tropical forests? An evaluation of the palatable forage hypothesis. Oikos, 92: 169-177.

Forti, L. C., Andrade, M. L. de, Andrade, A. P. P., Lopes, J. F. S. \& Ramos, V. M. (2006). Bionomics and identification of Acromyrmex (Hymenoptera: Formicidae) through an illustrated key. Sociobiology, 48: 1-18.

Gonçalves, C. R. (1961). O gênero Acromyrmex no Brasil (Hymenoptera: Formicidae). Studia Entomologica, 4: 113-180.

Hölldobler, B. \& Wilson, E. O. (1990). The ants. Cambridge: Harvard University Press, 732 p.

Jaffé, K. \&Vilela, E. (1989). On nest densities of the leaf-cutting ant Atta cephalotes in tropical primary forest. Biotropica, 21: 234-236.

Krebs, C. J. (1989). Ecological methodology. New York, Harper and Hall, $654 \mathrm{p}$.

Mundim, F.M., Bruna, E.M., Vieira-Neto, E.H.M. \& Vasconcelos, H.L. (2012). Attack frequency and the tolerance to herbivory of Neotropical savanna trees. Oecologia, 168: 405-414. doi: 10.1007/s00442-011-2088-8

Nickele, M.A., Reis Filho, W., Oliveira, E.B. de. \& Iede, E.T. (2009). Densidade e tamanho de formigueiros de Acromyrmex crassispinus em plantios de Pinus taeda. Pesquisa Agropecuária Brasileira, 44: 347-353.

Nickele, M. A., Oliveira, E. B. de., Reis Filho, W., Iede, E. T. \& Ribeiro, R. D. (2010). Distribuição Espacial de Formigueiros de Acromyrmex crassispinus (Forel) (Hymenoptera: Formicidae) em Plantios de Pinus taeda L. Neotropical Entomology, 39: 862-872. 
Nickele, M.A., Pie, M.R. \& Reis Filho, W. (2012a). Emigration of a colony of the leaf-cutting ant Acromyrmex heyeri (Forel) (Hymenoptera: Formicidae). Revista Brasileira de Entomologia, 56: $385-386$.

Nickele, M. A., Reis Filho, W., Oliveira, E. B. de, Iede, E. T., Caldato, N. \&Strapasson, P. (2012b). Attack of leaf-cutting ants in initial pine plantations and growth of plants artificially defoliated. Pesquisa Agropecuária Brasileira, 47: 892-899.

Pereira, R. de C., Della Lucia, T.M.C. \& Mayhé-Nunes, A.J. (1999). Levantamento de Attini (Hymenoptera: Formicidae) em povoamentos de Eucalyptus grandis W. Hill ex Maiden em Minas Gerais. Revista Árvore, 23: 341-349.

Peñaloza, C. \& Farji-Brener, A. G. (2003). The importance of treefall gaps as foraging sites for leaf-cutting ants depends on forest age. Journal of Tropical Ecology, 19: 603-605. doi:10.1017/S0266467403003675

Rando, J.S.S. \& Forti, L.C. (2005). Ocorrência de formigas Acromyrmex Mayr, 1865, em alguns municípios do Brasil. Acta Scientiarum. Biological Sciences, 27: 129-133.

Reis Filho, W. \& Oliveira, S. de. (2002). Atividade externa, carregamento de isca granulada e controle de Acromyrmex crassispinus em floresta de Pinus taeda. Colombo: Embrapa Florestas, 3 p. (Comunicado Técnico, 78).

Silva Junior, M.R., Castellani, M.A., Moreira, A.A., D'Esquivel, M., Forti, L.C. \& Lacau, S. (2013). Spatial distribution and architecture of Acromyrmex landolti Forel (Hymenoptera, Formicidae) nests in pastures of Southwestern Bahia, Brazil. Sociobiology, 60: 20-29. doi: 10.13102/ sociobiology.v60i1.20-29
Sousa-Souto, L., Viana-Junior, A.B. \& Nascimento, E.S. (2013). Spatial Distribution of Acromyrmex balzani (Emery) (Hymenoptera: Formicidae: Attini) Nests Using Two Sampling Methods. Sociobiology, 60: 162-168. doi: 10.13102/sociobiology. v60i2.162-168

Vasconcelos, H. (1990). Habitat selection by the queens of the leaf-cutting ant Atta sexdens L. in Brazil. Journal of Tropical Ecology, 6: 249-252.

Vasconcelos, H.L. \& Cherrett, J.M. (1997). Leaf-cutting ants and early forest regeneration in central Amazonia: effects of herbivory on tree seedling establishment. Journal of Tropical Ecology, 13: 357-370.

Weber, N. A. (1972). Gardening-ants: the attines. Philadelphia: American Philosophical Society, 146 p.

Wetterer, J.K. (1994). Ontogenetic changes in foragerpolymorphism and foraging ecology in the leaf-cutting ant Atta cephalotes. Oecologia, 98: 235-238.

Ying, G.G. \& Kookana, R.S. (2006). Persistence and movement of fipronil termiticide with under slab and trenching treatments. Environmental Toxicology and Chemistry, 25: 2045-2050.

Zanetti, R., Vilela, E. F., Zanúncio, J. C., Leite, H. G. \& Freitas, G. D. (2000). Influência da espécie cultivada e da vegetação nativa circundante na densidade de sauveiros em eucaliptais. Pesquisa Agropecuária Brasileira, 35: 1911-1918.

Zanuncio, J. C., Lopes, E. T., Zanetti, R., Pratissoli, D. \& Couto, L. (2000). Spatial distribuition of nests of the leaf-cutting ant Atta sexdens rubropilosa (Hymenoptera: Formicidae) in plantationsof Eucalyptus urophylla in Brasil. Sociobiology, 39: 231-242. 